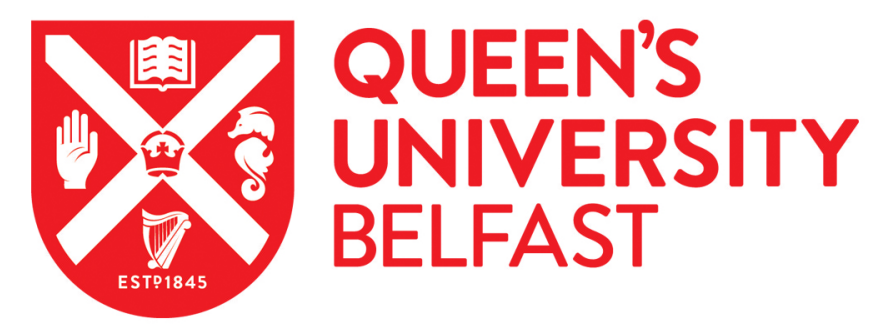

\title{
Research with children: methodological issues and innovative techniques
}

Fargas Malet, M., McSherry, D., Larkin, E., \& Robinson, C. (2010). Research with children: methodological issues and innovative techniques. Journal of Early Childhood Research, 8(2), 175-192. https://doi.org/10.1177/1476718X09345412

Published in:

Journal of Early Childhood Research

Document Version:

Peer reviewed version

Queen's University Belfast - Research Portal:

Link to publication record in Queen's University Belfast Research Portal

Publisher rights

(c) The Author(s), 2010.

\section{General rights}

Copyright for the publications made accessible via the Queen's University Belfast Research Portal is retained by the author(s) and / or other copyright owners and it is a condition of accessing these publications that users recognise and abide by the legal requirements associated with these rights.

Take down policy

The Research Portal is Queen's institutional repository that provides access to Queen's research output. Every effort has been made to ensure that content in the Research Portal does not infringe any person's rights, or applicable UK laws. If you discover content in the Research Portal that you believe breaches copyright or violates any law, please contact openaccess@qub.ac.uk. 


\title{
Research with Children: Methodological Issues and Innovative
}

\section{Techniques}

\begin{abstract}
In the past few decades, a growing body of literature examining children's perspectives on their own lives has developed within a variety of disciplines, such as sociology, psychology, anthropology and geography. This paper provides a brief upto-date examination of methodological and ethical issues that researchers may need to consider when designing research studies involving children; and a review of some of the methods and techniques used to elicit their views. The paper aims to encourage researchers to critically reflect on these methodological issues and the techniques they choose to use, since they will have implications for the data produced.
\end{abstract}

Key words: research with children, methodology, research methods

Until relatively recently, research was fundamentally on children, rather than with children or for children (Mayall, 2000; O'Kane, 2000; Darbyshire et al., 2005). Historically, children were seen as objects to be studied, being regarded as incompetent, unreliable and incomplete (e.g. Barker and Weller, 2003). However, with the emergence of the 'new social studies of childhood' (James, Jenks, and Prout, 1998) and the children's right discourse (the United Nations Conventions on the Rights of the Child, 1989 (1); the Children's Act, 2004), children are now viewed as social actors who are 'experts' on their own lives (e.g. Mauthner, 1997; Kellett and Ding, 2004). 
This new approach has meant a methodological shift, involving the emergence of new 'participatory' research methodologies, the adaptation of more traditional methods, such as observation and questionnaires (Punch, 2002a), and the development of multi-method approaches, such as the 'mosaic approach', developed by Clark and Moss (2001). As well as that, in recent years, children have started to become involved in the various stages of the research process, such as formulating the research questions, planning the methodology, collecting and/or analysing data, drafting recommendations and disseminating findings (Coad and Evans, 2008). This has involved differing levels of control-sharing and of participation in the research process (Brownlie et al., 2006; Alderson, 2000; McNeish, 1999).

It has been argued that the particular internal images of childhood that researchers hold will inform their choice of methods, ethical practice, analysis, and interpretation of data (O'Kane, 2000; Mayall, 2000; Punch, 2002a; Christensen and Prout, 2002). Punch (2002a) identified three different approaches to research with children:

- one which considers children as practically the same as adults and employs the same methods as those used with them;

- one which perceives children as completely different from adults and uses ethnography (participant observation) to examine the child's world; and

- one which understands children as similar to adults but with different competencies, and which has developed a plethora of innovative and adapted techniques.

This paper seeks to review a range of methodological approaches, in addition to practical and ethical considerations that have emerged in research conducted with young children. 


\section{Research with children: Methodological and ethical considerations}

This section focuses upon methodological and ethical considerations identified in previous research with children, including: gaining access and seeking consent; the research setting; questions and activities during data collection; confidentiality and child protection issues; and debriefing and rewards.

\section{Gaining access and seeking consent}

When undertaking research with children, researchers must gain the co-operation of a range of different 'gatekeepers', such as school staff and parents (Cree et al., 2002). This process can range in complexity depending upon the situation. For example, researching children in care or adopted can be quite complex in terms of gaining access and seeking consent because of the potentially large number of gatekeepers involved, such as social workers, Social Services managers, birth parents, adoptive parents, and foster carers (Hepinstall, 2000; McSherry et al., 2008).

Informed consent should be freely given (without coercion, threat or persuasion) by children who can make an appropriately informed decision. Competent minors less than 16 years old of age can give consent, with competence being defined as having enough knowledge to understand what is proposed and enough discretion to be able to make a wise decision in light of one's own interests (Alderson and Morrow, 2004). However, it has often been assumed that 'children are not competent enough to give their informed consent, that this needs to be gained from a 'more competent adult' and the simpler level of 'assent' (agreement to participate) is sufficient from the child' (Kellet and Ding, 2004: 166). Some researchers have questioned this assumption and claim that children are fully capable of giving their informed consent. In fact, in several research studies, researchers have prioritised children as the key consentcore (e.g. Munford and Sanders, 2004). There are also examples where researchers 
have sought active consent from children and passive agreement from their parents/carers (e.g. Morrow, 2001; Thomas and O'Kane, 1998).

Cocks (2006) argues that the notion of consent might exclude some children, such as disabled or refugee children, since it might not always be possible to obtain in those particular contexts. She endorses the concept of 'assent' as a sensitive and appropriate option to include all children in research on issues that affect them, and argues that the notion of 'assent' 'removes the reliance on the child demonstrating adult-centric attributes such as maturity, competence and completeness' (Cocks, 2006: 257). In her own research with children with learning impairments, she assessed children's assent by being attentive to the children's behaviour and responses towards her at all times. Similarly, Cree and colleagues (2002) point out that when researching very young people, their like or dislike in taking part can be identified, since they may show it in different ways, such as crying or refusing to engage with materials or the researcher.

Researchers have used information leaflets, tapes, letters and oral presentations to explain the research project to children, their parents/carers and other gatekeepers such as social workers or teachers (e.g. Barker and Weller, 2003; Thomas et al., 1999; and Morgan et al., 2002). A recent innovation in this area has been the use of a DVD as a friendly and relaxed way to introduce a research study to children, and what taking part would entail (2). This study is focused upon children's pathways through care, and involves interviews with children who have been adopted from care, who have remained in care on a long-term basis, and who have returned home from care (McSherry et al., 2008). The interviews deal with issues such as the child's concept of family, belonging and identity. The use of the DVD was deemed particularly important given the potentially sensitive nature of the interview subject matter. 
The quality of information provided to potential participants is very important, since as Bogolub and Thomas (2005) argue, the ability to give informed consent depends on the quality of the explanation. In leaflets, simple language (e.g. short sentences, no jargon or acronyms, the active voice rather than the passive one, and requests rather than commands), the use of diagrams, speech bubbles or pictures, and large print are strongly recommended. It is also found to be useful to break the information up into short sections, with subheadings or through a question and answer format; and it is advisable to run through draft leaflets with children and ask for their views (e.g. Alderson, 2004; Alderson and Morrow, 2004).

\section{Context / location}

When planning a research project, it is important to bear in mind that the research context might affect what children will talk about (Hill, 2006; Barker and Weller, 2003; Punch 2002a; O'Kane, 2000; Scott, 2000; Backett-Milburn and McKie, 1999). A difficulty of many settings in conducting research with young children is negotiating privacy (Mauthner, 1997) and keeping confidentiality (Barker and Weller, 2003).

Although collecting data at schools seems to be more cost-effective than at home (Scott, 2000), different problems or difficulties have been identified concerning the school setting. For example, once school staff members have given consent, children might find it difficult to decline to take part (Backett-Milburn and McKie, 1999). It has been observed that, although the vast majority of children in a school class setting would agree to participate, a minority will just write/draw minimally and/or say barely anything (Morrow, 2001). Other concerns regarding the school setting are: limitations of timetables, difficulties in finding available spare rooms (Punch, 2002b; Kellet and Ding, 2004), and the risk of children interpreting participation in the research as 
'school work' (Kellet and Ding, 2004), thus perceiving the researcher in a 'teacher' role (Goodenough et al., 2003; Hill, 2006) and feeling pressured to give the 'right' answers to the research questions (Punch, 2002a). Therefore, children might say what they think adults want them to say (Clark, 2005; Backett-Milburn and McKie, 1999). Researchers have tried to minimise these risks by emphasizing and reassuring children that there are no right or wrong answers (Punch, 2002a), and by choosing appropriate rooms in the school setting, such as art/activities rooms (Darbyshire et al., 2005), the 'resource' room (Goodenough et al., 2003) or the storecupboard (Jones, 2008), which represent an in-between of the formal and informal worlds of the school.

Using the child's own home as a location can also entail some difficulties. Interviews at home are probably more time-consuming and costly (Scott, 2000). Researchers need to negotiate their social position as a guest in children's homes, since this is not clearly defined (Mayall, 2000). Finding a private and quiet space in the home can be problematic due to child protection issues (Barker and Weller, 2003), thus parents or carers might wish to be present, and that might influence children's responses (Scott, 2000).

\section{Data collection: Questions and activities}

In order to establish rapport, it is advisable to start asking about things the child already knows or sees as relatively unthreatening (Cameron, 2005), such as specific daily events, routines or feelings (happiest, saddest, most embarrassing event) (Mauthner, 1997). A period of 'free narrative' has also been recommended when starting an interview, as facilitating 'both the child's settling-in phase and the interviewer's grasp of this child's communication style and concerns' (Cameron, 2005: 601). When the research involves sensitive issues, it is advisable to present less 
difficult questions first (Wood Charleswort and Rodwell, 1997). The researcher should be constantly alert to children's responses (e.g. falling silent or changing the subject suddenly), in order to respect children's reluctance to answer questions that might be difficult or painful for them (Kay et al., 2003). Some research participants might agree to participate but appear to be unwilling, shy or embarrassed throughout the research. Some might become more involved with gentle prompting. Alderson and Morrow (2004: 53) suggest that if it becomes clear that a child does not wish to continue, 'it is respectful to talk for a while and then end the interview positively and thank them without suggesting it may have been a waste of time'.

When interviewing children, it is particularly appropriate for the researcher to use non-verbal behaviours (e.g. keeping eye contact, sounds like 'mm' or 'really', and head nods) and verbal prompts (such as 'tell me more about that'), which indicate that the interviewer is listening and wants to hear the child's story (Cameron, 2005). Exclamations such as 'Great!', 'Terrific!' or 'Cool!' may not be that suitable, as they 'may discourage the child from telling the whole story which includes the 'non-cool' parts!' (Cameron, 2005: 603).

Interviewers are recommended to avoid using closed questions when interviewing young children (and even adults), and use open or wh-questions when possible (Waterman, Blades and Spencer, 2001). When closed questions are required, researchers might prefer to use follow-up questions to make sure that the interviewee is not just guessing an answer.

Researchers might want to ask questions about issues that are pertinent and related to children's own experiences (Scott, 2000), as young children tend to give monosyllabic answers to questions that they do not consider relevant to them (Morgan et al., 2002). It may be inappropriate to ask too many questions (or too few) 
(Mauthner, 1997; Cameron, 2005). Further clarity of language is considered essential (Punch, 2002a). It is advisable to avoid complex and over-simple words, and notions that restrict children into giving only trivial responses (Alderson, 2000).

A wide range of activities and techniques have been used in interviews and focus groups with young children, in order to make them more fun and interesting, and to give children more control over the focus and agenda (e.g. Sanders and Munford, 2005; Kay et al, 2003; Punch, 2002b). Using a mixture of materials and techniques provides children with time to think about what they would like to communicate, so they do not feel pressured to give a rapid answer (Punch, 2002b), as well as giving them choice and control on how to express themselves, and assist them in talking about more complicated, sensitive, and abstract issues (Thomas and O'Kane, 1998).

Some researchers have used breaks during focus groups with children, such as group activities and refreshments (Morgan et al., 2002) or a food break (Goodenough et al., 2003), to keep children engaged and focused, as well as giving some extra non-structured informal time with them.

\section{Confidentiality and child protection issues}

Additional issues come into play with respect to confidentiality in research with young children, such as parents' curiosity and concern for their child as well as child protection regulations. Parents may tend to ask their child or the researcher about the content of the interview and that might put stress on the child (Masson, 2004) and on the researcher (Bushin, 2007). Furthermore, children might reveal that they are seriously harmed or ill-treated, or the researcher, when interviewing a child, might identify a medical condition or learning difficulty which the parents could take action about 
Children should be informed about the limitations of confidentiality before participating in the research in order to enable them to give fully informed consent (Williamson et al, 2005). When interviewing young children, this could 'be expressed as the difference between what can be 'just between you and me' and what may need to be told to others 'to stop someone from getting hurt" (Thompson and Rudolph, 2000: 35). Thus, it is common practice that if children disclose abuse, researchers will encourage the child to talk to adults who could help or else to agree that the researcher should talk to them (Alderson and Morrow, 2004). However, what should the researcher do when abuse is disclosed by the child and she or he does not agree to talk to somebody that can help? And how does the researcher identify what is 'harm' that needs reporting? Researchers have adopted different approaches. For instance, Lynch and colleagues (1999), in their study with children who had been sexually abused, had clear from the start that if a child disclosed information that raised concerns about her/his safety, they would try to persuade him/her to speak to those concerned with his/her welfare, and if that did not work, confidentiality would be breached. Their position was specified in a Code of Confidentiality, which was accessible to the participants prior to the interview. In contrast, Hill (2006) argues that sensitive information or any information given by a child should only be disclosed to others when the child consents to that, after having discussed it with him/her.

Data collection: debriefing and rewards

After the interview, it might be appropriate to have some debriefing (Clark, 2005), and suitable support might be needed in cases where the participants' feelings may become overwhelming (Kay et al., 2003). 
Giving payments (whether cash or vouchers) to participants is a somewhat controversial issue. Those who are against this practice argue that payments can pressurise people into taking part in the research and into saying what they think researchers want to hear. On the other hand, it may be argued that payments should be given as an acknowledgement of the participants' time and contribution. While some ethical guidelines have advocated for this practice (Children in Scotland, 2001), others are strongly against it, and an EU Directive (L121/34) from 2001 advised that paying children to take part in research should be illegal (Cree et al., 2002).

Cree and others (2002) decided not to pay or give vouchers to the participants in their research, but to offer them a pack of paper and pens as a sign of their gratitude. In contrast, Bushin (2007) decided to give a 'thank you' voucher to children, but only informed them about the voucher during the interviews with them, rather than prior to participating in the research, since that might have acted as an incentive.

\section{Techniques, methods and tools when researching children}

Various methods and techniques have been used when conducting research with children. However, it has been argued that researchers need to critically reflect on the methods and techniques they use and the ways they use them (Barker and Weller, 2003; Sanders and Munford, 2005). The methodology chosen needs to match the research questions of the project, respect limitations of time and resources, be sensitive and ethical, and take into account the particular characteristics and needs of the participants, as well as the cultural and physical setting where it takes place (e.g. Christensen and Prout, 2002; Punch, 2002a). 


\section{Using photography}

Researchers have employed photography in their studies in a variety of ways. For instance, researchers are increasingly asking children to take their own photographs to be used later as interview stimuli, rather than using other people's pictures; since children's own photographs are probably more likely to reflect what matters to them (Samuels, 2004). In addition, children's own pictures can be used in an interview as an instrument to help children develop their answers to particular questions and at the same time, to enable children to express facets of their lives in a very unique way (Clark-Ibáñez, 2004: 1512). They can also act as prompts to a child's personal story (Newman et al., 2006). Researchers usually use disposable or instant cameras, since they are relatively economical and simple to use.

Photovoice was one of the methods used by Darbyshire and colleagues (2005) in their study on children's perspectives on physical activity. This technique does not involve interviews; but children write briefly what their photographs mean. Dockett and Perry (2005) used a similar method in a study where they asked children to take photographs in small groups (2-3) around the school. A classroom book was created with the pictures and the children's comments, which were recorded while they planned, took and reviewed the photographs. Similarly, Kirova and Emme (2006) used fotonovelas (or photo novellas). In fotonovelas, the photographs are not only used to elicit discussion and dialogue, but are manipulated and organized in a narrative format.

There are a number of benefits to using photography as a tool for doing research with young children, particularly when interviewing. For example, using the participant's photographs may help to build and maintain rapport between interviewer and interviewee and may capture the interviewees' attention more easily and for longer. It also enables interviewees to choose what they talk about as the issues they 
feel represent their own experiences and views. Photographs can also give structure to the interview, provide a focus, and act as a clear and tangible prompt or as a means for remembering. Thus, they have proved to be a good way of eliciting relevant detailed information and rich descriptions from the participants, leading to 'a far deeper understanding than a simple conversation' would (Newman et al., 2006: 301). Further, photographs can evoke emotions and affectively charged responses (Samuels, 2004).

However, there may be some disadvantages in using photography when researching young children. For example, giving children freedom over their cameras means that the researchers do not have any idea or control over what photographs might be taken (Barker and Weller, 2003), thus the participant might use the camera in inappropriate ways, and some children might be tempted to take photographs of what they would like to keep as a picture afterwards (Punch, 2002a). It may pose ethical challenges concerning issues of confidentiality, since informed consent from all those who are in the photographs is nearly impossible to gain. Furthermore, there might be photographs that the interviewee regrets taking and that the researchers might have already seen when developing them. To avoid that, it would be good practice to explain to participants that they will be the first to view the photographs and have a chance to take out any 'regret' pictures (Clark-Ibáñez, 2004).

Not all children will engage in the same way with this method. Some children may be confident and experienced with cameras and enjoy the activity, while others may lose their camera, struggle to find inspiration or may be embarrassed about their photography skills, and just take very few pictures (Barker and Weller, 2003). 


\section{Drawings}

Drawing has been used as a (usually fun or enjoyable) way for children to express their own views and experiences. Until recently, researchers focused exclusively on what they understood the child's drawing meant rather than on the child's explanation of what the drawing was about. However, there appears to have been a shift of focus 'from what the children draw to what the children say about what they draw' (Driessnack, 2005: 420).

Children have been asked to draw in interviews in numerous research studies (e.g. Leonard, 2006; Barker and Weller, 2003; Morgan et al., 2002; Sartain et al., 2000; Miles, 2000). Drawing maps or plans is also a popular method in research with children; and it has been used in many studies to gather information about significant spaces for children and to explore their perceptions of these places (e.g. Leonard, 2007; Darbyshire et al., 2005; Morrow, 2001; Young and Barrett, 2001).

There are different reasons for using drawings in research with young children. Drawings can be used as a good ice-breaker, can help children relax and establish rapport, can act as prompts and as triggers for remembering or for eliciting discussion, and may help children organize their own narratives (Hill, 1997; Miles, 2000). This technique may also enable children to gain more control over the interview, since it gives children an opportunity to draw as much or as little as they like, and also gives them time to reflect on their own ideas (Miles, 2000). It has been described as a useful and fairly quick way to gain considerable amounts of information in a relatively short period of time.

However, there are a number of drawbacks to using drawing techniques with children. For example, not all children consider drawing to be fun and some children may be inhibited about their drawing capabilities. Older children may not wish to draw 
pictures, since they might see it as 'babyish'. In short, it may not suit all children. When using the technique in a classroom setting, drawings can be easily seen and copied by peers, and thus 'may illustrate socially constructed rather than individual ideas' (Leonard, 2006: 61). Children may draw what they find easy to portray or what they think would please the researcher or other adults. Finally, researchers using this method can be uncertain about how to analyse this kind of data (Backett-Milburn and McKie, 1999).

\section{Participatory techniques}

Participatory research techniques are now frequently used in interviews and focus groups with young children to serve different aims. They enable participants to create 'inclusive accounts using their own words and frameworks of understanding, via a range of exercises such as mapping, timelines, cartoons, matrices and pie charts' (Pain and Francis, 2003: 46). For instance, charts and diagrams have been used in a variety of studies as visual aids to enable children to express themselves in greater depth (see e.g. Thomas and O'Kane, 1998; Punch, 2002b; Christensen and James, 2000)

In grouping and ranking exercises, 'children are given a set of cards or photographs of activities or issues to rank in order of importance' (Clark, 2005: 494). A ranking exercise, the 'Diamond Ranking Exercise', was used in a group setting in order to explore the opinions of children in care in terms of what they found most important about contributing to decision-making (Thomas and O'Kane, 1998). Punch (2002b) used a similar activity in her study with young people on perceptions of their problems and coping strategies, where the participants grouped problems written onto cards into three different piles, representing big, middle and little worries, and 
ranked each pile from most to least worrying. The ranking exercise stimulated interesting discussions about the different problems.

Q methodology is another approach that utilises ranking exercises (see Brown, 1980; Mckeown and Thomas, 1988). Statements are drawn from discourses around the subject of investigation (the concourse), and these items are sorted by participants onto a grid designed to represent a normal distribution curve. Sorting takes place under the direction of a 'condition of instruction', based on 'more or less' (e.g. 'most representative of my opinion' to 'most unrepresentative of my opinion'). For added depth, it is customary to discuss and record participants' choices with them as they sort, thus providing a valuable source of qualitative information. Where $\mathrm{Q}$ methodology diverges from other ranking-exercises techniques is that each statement is coded, and the resultant sorts analysed using factor analysis (3). Finally, the researcher facilitates the interpretation of the emergent factors through an 'internal triangulation' process, based upon the arrangement of the sort, the content of the concourse and the meanings attached to the statements as described by the participants.

Two of the strengths of $\mathrm{Q}$ methodology, where research with young children is involved, are:

- The researcher is not limited to 'written' textual statements, being free to use pictures (Taylor et al., 1994), computer generated imagery (Burt et al., 2007 (4)), symbols (Kwon and Kim, 2006), "plasticine" sculptures (Svennungsen and Allgood, 2006) or even foods (Dunne and McConnell, 2007; Stewart et al., 2007); and

- It is adaptable to different modes of delivery, including face-to-face interview, postal sorts (Ellis et al., 2007), and using computer/web based software (Burt et al., 2007; Hackert, 2007). 


\section{Use of 'stimulus material' or prompts}

When interviewing children, researchers have made use of a range of prompts and materials to stimulate children's responses. Written prompts - such as sentence completion, wishes, word choice prompts, or unfinished stories to complete - have been widely used in interviews with children (Clark, 2005; Punch, 2002b; Morrow, 2001). Some research projects have also used picture prompts. For instance, Thomas and colleagues (1999), in their study with adoptive children, used pictorial prompt cards in some of their interviews, in order to facilitate communication with the children when talking about difficult times in their lives (i.e. issues related to their adoption process). The pictorial cards represented the different phases of the adoption process. They encouraged the children to see the adoption process as a journey, since when joined together in whatever order, they formed a road. If the children thought of other stages, they were invited to draw new cards.

Feelings faces or feelings cards have also been used especially to facilitate communication when asking about sensitive issues (Hill, 1997). Veale (2005), in her workshops or 'focus groups' with Rwandan children, introduced happy/sad drawings. The children were shown a drawing of a happy girl/boy and a sad girl/boy and asked to discuss what the child was probably thinking.

\section{Diaries and other life narrative techniques}

Young children have been encouraged to tell their own life stories in a wide range of ways and formats, such as life story books, memory books, diaries or life maps.

Diaries are especially useful to explore children's use and perception of time. However, for some children, diaries can be too much like school work, while for 
others might be a valuable form of communication. A difficulty might be ensuring confidentiality for diary extracts in both the school setting (where teachers and peers may put pressure to the child to participate) and at home (where parents may check the child's diary or even write their own entries) (Barker and Weller, 2003).

'Storygames' have been used when children's own stories may be deeply traumatic (e.g. children who have suffered the direct consequences of a conflict or genocide; see Veale, 2005). This involves children creating a story, where each child is invited to give a line of the story and the story goes from one child to another until it is finished.

Life story books have been frequently used in social work practice with foster and adopted children (Cook-Cottone and Beck, 2007), but also to research people with learning disabilities (Hewitt, 2000), and as a therapeutic tool in family therapy with traumatised children (Hanney and Kozlowska, 2002). Life story books allow children and others to make sense of their past experiences and enable them to talk about themselves in a structured way, helping them to build their own identity. They usually include photographs, drawings, words and documents that give a chronological account of the child's story. Their format is flexible in the sense that they could be an album of photos with text, a box or even a timeline (Cook-Cottone and Beck, 2007). A story book has recently been designed and developed to use, as an interview schedule, in a study looking at the experiences of children who have been adopted from care, who have remained in care on a long-term basis, and who have returned home from care (McSherry et al., 2008). It is a 'task-based' (Punch, 2002a) tool that will allow children to express their own views, according to their own level of ability. Each page refers to a particular topic (e.g. my family, school, or the future), and involves an activity, such as drawing, using stickers or circling pictures. Each topic or 
question is broad enough to allow the child to talk freely about a particularly issue, thus giving the child a certain degree of control over the interview.

\section{Observation}

There seems to be a long tradition of observation as a method for researching young children, particularly in the fields of early years' education (Clark, 2005) and developmental psychology (Hill, 1997). However, in child and family social work research, this method has been barely employed, partly due to reluctance to intrude in people's homes (Hill, 1997). Observation has been regarded as especially suited for researching very young children, but not as useful for older children, who can be interviewed instead, since as children grow up, they become more aware of the presence of observers (Dunn, 2005).

Participant observation is a form of observation that involves 'watching, listening, reflecting and also engaging with the children in conversation' (Mayall, 2000: 121). An example of a study using this method is the 'Healthy Eating Project', described by Mauthner (1997), where researchers observed children eating during mealtimes, as well as talking about food, and cooking and serving food. The researcher ate and sat with the children during lunchtime, and observed what foods children selected, how they picked the food, and what they actually ate.

\section{Questionnaires}

Although less popular than other methods, questionnaires have been used with children and young people, often using a more 'child-friendly' format. For instance, The British Household Panel Study used a pre-recorded questionnaire, which was played on a personal stereo and was answered by children in a booklet at their own 
pace (Scott, 2000). Other researchers have used questionnaires in which children were asked to draw faces to show how they felt about certain activities (Clark, 2005).

Apart from self-completion questionnaires completed at home or at school, questionnaires can also be completed on a computer or by telephone. Computer Assisted Personal Interviewing (CAPI) has been praised since it provides the chance to incorporate videos and audio stimuli that lessen the need to rely just on verbal questioning. Telephone interviewing has been effectively used with children aged over 10 in the USA, although lack of privacy can be a major weakness of this technique (Scott, 2000).

Questionnaires may have some advantages, including: being relatively quick to administer; their potential capacity to collect large amounts of standard data and reach large samples; and the fact that some children might find it easier to answer questions in this way rather than face-to-face with a stranger (Hill, 1997). However, they also have disadvantages. For example, return rates are usually low and questionnaires require a certain level of literacy; and not all children find it easy to communicate well in writing. It has been argued that 'many young people find questionnaires irrelevant or difficult to complete' (Hill, 1997: 175). Young children may response to a question, even if they do not know the answer. Finally, children's answers will also be dependent on biases such as social desirability, context effects and acquiescence bias (Scott, 2000).

\section{Conclusions}

Researchers, conducting research with children, have developed new and adapted old social research methods and tools to fit the aims and objectives of their studies and the characteristics and needs of the research participants. However, the 
disadvantage and limits of, as well as the reasons for, using innovative/traditional methods and techniques with young children might need to be reflexively and critically approached; for instance, 'are certain methods being used with children purely because they are fun, or because they also generate useful and relevant data?' (Punch, 2002a: 330).

This review is intended to encourage researchers to reflect upon the research methods and approaches that they use with young children, and the most appropriate way in which to apply them, in order to, as far as possible, diminish their drawbacks and maximize their benefits. As Hill (1997: 180) argues, 'It is important that research-based publications give details of the methods used and provide assessments and feedback about how satisfactory were particular techniques'.

\section{Notes}

1. Particularly article 12 which states that children have the right to articulate their opinions regarding decisions that affect them and to be listened to; and article 13 which states that children have the right to seek, get and share information (cf. Alderson, 2000).

2. A DVD is currently being used in the Northern Ireland Care Pathways and Outcomes study (a copy of it can be viewed at: http://www.qub.ac.uk/iccr/).

3. See Brown (1980) 'Part II: Technical Procedures', for a comprehensive discussion of the factor analysis technique employed in Q methodology.

4. See also: http://face.dur.ac.uk/info/wakka.php?wakka=Home/qsort/rsoc 


\section{References}

Alderson, P. (2000) 'Children as Researchers. The Effects of Participatory Rights on Research Methodology', in P. Christensen and A. James (eds) Research with Children. Perspectives and Practices, pp. 241-257. London: RoutledgeFalmer.

Alderson, P. (2004) 'Ethics', in S. Fraser, V. Lewis, S. Ding, M. Kellet, and C. Robinson (eds) Doing Research with Children and Young People, pp. 97-112. London: The Open University.

Alderson, P. and Morrow, V. (2004) Ethics, social research and consulting with children and young people. Essex: Barnado's.

Backett-Milburn, K. and McKie, L. (1999) 'A critical appraisal of the draw and write technique'. Health Education Research. Theory \& Practice 14(3): 387-398.

Barker, J. and Weller, S. (2003) "Is it Fun?" Developing Children Centred Research Methods'. International Journal of Sociology and Social Policy 23(1/2): 33-58.

Bogolub, E.B. and Thomas, N. (2005) 'Parental Consent and the Ethics of Research with Foster Children: Beginning a Cross-Cultural Dialogue'. Qualitative Social Work 4(3): 271-292.

Brown, S.R. (1980) Political Subjectivity: Applications of Q Methodology in Political Science. New Haven: Yale University Press.

Brownlie, J., Anderson, S. and Ormston, R. (2006) Children as Researchers. SEED Sponsored Research. 
Burt, D.M., Kentridge, R.W., Good, J.M.M., Perrett, D.I., Tiddeman, B.P. and Boothroyd, L.G. (2007) 'Q-cgi: New techniques to assess variation in perception applied to facial attractiveness'. Proceedings of the Royal Society B (Biological Sciences) 274 (1627): 2779-2784.

Bushin, N. (2007) 'Interviewing with Children in their Homes: Putting Ethical Principles into Practice and Developing Flexible Techniques'. Children's Geographies 5(3): 235-251.

Cameron, H. (2005) 'Asking the tough questions: a guide to ethical practices in interviewing young children'. Early Child Development and Care 175(6): 597-610.

Children's Act (2004) London: Stationery Office (November, 2004).

Children in Scotland (2001) Research/Consultation Guidelines. Edinburgh: CiS.

Christensen, P. and James, A. (2000) 'Childhood Diversity and Commonality. Some Methodological Insights', in P. Christensen and A. James (eds) Research with Children. Perspectives and Practices, pp. 160-178. London: RoutledgeFalmer.

Christensen, P. and Prout, A. (2002) 'Working with Ethical Symmetry in Social Research with Children'. Childhood 9(4): 477-497.

Clark, A. (2005) 'Listening to and involving young children: A review of research and practice'. Early Child Development and Care 175(6): 489-505. 
Clark, A. and Moss, P. (2001) Listening to Young Children. The Mosaic approach. London: National Children's Bureau and Joseph Rowntree Foundation.

Clark-Ibáñez, M. (2004) 'Framing the Social World with Photo-Elicitation Interviews'. American Behavioral Scientist 47: 1507-1527.

Coad, J. and Evans, R. (2008) 'Reflections on Practical Approaches to Involving Children and Young People in the Data Analysis Process'. Children and Society 22(1): 41-52.

Cocks, A.J. (2006) 'The Ethical Maze: Finding and inclusive path towards gaining children's agreement to research participation'. Childhood 13(2): 247-266.

Cook-Cottone, C. and Beck, M. (2007) 'A Model for Life-Story Work: Facilitating the Construction of Personal Narrative for Foster Children', Child and Adolescent Mental Health 12(4): 193-195.

Cree, V.E., Kay, H. and Tisdall, K. (2002) 'Research with children: sharing the dilemmas'. Child and Family Social Work 7: 47-56.

Darbyshire, P., MacDougall, C. and Schiller, W. (2005) 'Multiple methods in qualitative research with children: more insight or just more?'. Qualitative Research 5(4): 417-436.

Dockett, S. and Perry, B. (2005) "'You Need to Know How to Play Safe": children's experiences of starting school'. Contemporary Issues in Early Childhood 6(1): 4-18. 
Driessnack, M. (2005) 'Children's Drawings as Facilitators of Communication: A Meta-Analysis'. Journal of Pediatric Nursing 20(6): 415-423.

Dunn, J. (2005) 'Naturalistic observations of children and their families', in S. Greene and D. Hogan (eds) Researching Children's Experience. Approaches and Methods, pp. 87-101. London: Sage Publications.

Dunne, L., and McConnell, B. (2007) 'Implications of local research for young children, parents and professionals'. Early Years Magazine. Belfast: Early years - the organisations for young children (NIPPA).

Ellis, G., Barry, J. and Robinson, C. (2007) 'Many ways to say 'no', different ways to say 'yes': Applying Q-methodology to understand public acceptance of wind farm proposals'. Journal of Environmental Planning and Management 50(4): 517-551.

Goodenough, T., Williamson, E., Kent, J. and Ashcroft, R. (2003) "'What Did You Think About That?" Researching Children's Perceptions of Participation in a Longitudinal Genetic Epidemiological Study'. Children and Society 17: 113-125.

Hackert, C. (2007) FlashQ [computer programme] Hackert.biz

Hanney, L. and Kozlowska, K. (2002) 'Healing Traumatized Children: Creating Illustrated Storybooks in Family Therapy'. Family Process 41(1): pp. 37-65.

Hepinstall, E. (2000) 'Gaining access to looked after children for research purposes: lessons learned'. The British Journal of Social Work 30(6): 867-72. 
Hewitt, H. (2000) 'A life story approach for people with profound disabilities'. British Journal of Nursing 9(2): 90-15.

Hill, M. (1997) 'Research Review: Participatory research with children'. Child and Family Social Work 2: 171-183.

Hill, M. (2006) ‘Children's Voices on Ways of Having a Voice: Children's and young people's perspectives on methods used in research and consultation'. Childhood 13(1): 69-89.

James, A., Jenks, C. and Prout, A. (1998) Theorizing childhood. Cambridge: Polity.

Jones, K. (2008) '“It's well good sitting in the storecupboard just talking about what we do": considering the spaces/places of research within children's geographies'. Children's geographies 6(3): 327-332.

Kay, H., Cree, V., Tisdall, K. and Wallace, J. (2003) 'At the Edge: Negotiating Boundaries in Research with Children and Young People'. Forum: Qualitative Social Research 4(2). http://www.qualitative-research.net/fqs/

Kellett, M. and Ding, S. (2004) 'Middle childhood', in S. Fraser, V. Lewis, S. Ding, M. Kellet and C. Robinson (eds) Doing Research with Children and Young People, pp. 161-174. London: The Open University.

Kirova, A. and Emme, M. (2006) 'Using Photography as a Means of Phenomenological Seeing: "Doing Phenomenology" with Immigrant Children'. The Indo-Pacific Journal of Phenomenology 6 (Special Edition): 1-12. www.ipjp.org 
Kwon. H.J. and Kim, H.K. (2006) 'Preference Factors in Symbol Mark Design'. Journal of Human Subjectivity 4(1): $61-70$.

Leonard, M. (2007) 'Trapped in space? Children's accounts of risky environments'. Children and Society 21: 432-445.

Leonard, M. (2006) 'Children's drawings as a methodological tool: Reflections on the eleven plus system in Northern Ireland'. Irish Journal of Sociology 15(2): 52-66.

Lynch, M. A., Glaser, D., Prior, V. and Inwood, V. (1999) 'Following up children who have been abused: Ethical considerations for research design'. Child Psychology \& Psychiatric Review 4(2): 68-75.

Masson, J. (2004) 'The legal context', in S. Fraser, V. Lewis, S. Ding, M. Kellet and C. Robinson (eds) Doing research with children and young people, pp. 43-58. London: The Open University.

Mauthner, M. (1997) 'Methodological Aspects of Collecting Data from Children: Lessons from Three Research Projects'. Children \& Society 11: 16-28.

Mayall, B. (2000) 'Conversations with Children. Working with Generational Issues', in P. Christensen and A. James (eds) Research with Children. Perspectives and Practices, pp. 120-135. London: RoutledgeFalmer.

McKeown, B. and Thomas, D. (1988) Q Methodology. London: SAGE Publications. 
McNeish, D. (1999) 'Promoting participation for children and young people: some key questions for health and social welfare organisations'. Journal of Social Work Practice 13(2): 191-203.

McSherry, D., Larkin, E., Fargas, M., Kelly, G., Robinson, C., Macdonald, G., Schubotz, D. and Kilpatrick, R. (2008) From care to where? A care pathways and outcomes report for practitioners. Belfast, Institute of Child Care Research, Queen's University.

Miles, G.M. (2000) 'Drawing together hope: 'listening' to militarised children'. Journal of Child Health Care 4(4): 137-142.

Morgan, M., Gibbs, S., Maxwell, K. and Britten, N. (2002) 'Hearing children's voices: methodological issues in conducting focus groups with children aged 7-11 years'. Qualitative Research 2(5): 5-20.

Morrow, V. (2001) 'Using qualitative methods to elicit young people's perspectives on their environments: some ideas for community health initiatives'. Health Education Research. Theory \& Practice 16(3): 255-268.

Munford, R. and Sanders, J. (2004) 'Recruiting Diverse Groups of Young People to Research: Agency and Empowerment in the Consent Process'. Qualitative Social Work 3(4): 469-482.

Newman, M., Woodcock, A. and Dunham, P. (2006) "Playtime in the Borderlands": Children's Representations of School, Gender and Bullying through Photographs and Interviews'. Children's Geographies 4(3): 289-302. 
O'Kane, C. (2000) 'The Development of Participatory Techniques. Facilitating Children's Views about Decisions which affect them', in P. Christensen and A. James (eds) Research with Children. Perspectives and Practices, pp. 136-159. London: RoutledgeFalmer.

Pain, R. and Francis, P. (2003) 'Reflections on participatory research', Area 35(1): 46-54.

Punch, S. (2002a) 'Research with Children: The Same or Different from Research with Adults?'. Childhood 9(3): 321-341.

Punch, S. (2002b) 'Interviewing Strategies with Young People: the 'Secret Box', Stimulus Material and Task-based Activities'. Children and Society 16: 45-56.

Samuels, J. (2004) 'Breaking the Ethnographer's Frames: Reflections on the Use of Photo Elicitation in Understanding Sri Lankan Monastic Culture'. American Behavioral Scientist 47: 1528-1550.

Sanders, J. and Munford, R. (2005) 'Activity and Reflection: Research and Change with Diverse Groups of Young People'. Qualitative Social Work 4(2): 197-209.

Sartain, S.A., Clarke, C.L. and Heyman, R. (2000) 'Hearing the voices of children with chronic illness'. Journal of Advanced Nursing 32(4): 913-921.

Scott, J. (2000) 'Children as Respondents. The Challenge for Quantitative Methods', in P. Christensen and A. James (eds) Research with Children. Perspectives and Practices, pp. 98-119. London: RoutledgeFalmer. 
Stewart, M.C., Sneddon, H., Dunne, L., Gildea, A., Sloan, S., McErlean, L. and Iwaniec, D. (2007) 'Glad study summary and recommendations'. Child Care in Practice 13(3): 271-280.

Svennungsen, H. and Allgood, E. (2006) 'Intensive Q-study on personal development using pictures: working paper'. Paper presented at the International Society for the Scientific Study of Subjectivity Annual Conference. Trondheim, Norway

Taylor, P., Delprato, D.J. and Knapp, J.R. (1994) 'Q-Methodology in the study of child phenomenology'. Psychological Record 44(2): 171-183.

Thomas, C., Beckford, V., Lowe, N. and Murch, M. (1999) Adopted Children Speaking. London: British Agencies for Adoption and Fostering.

Thomas, N. and O'Kane, C. (1998) 'The Ethics of Participatory Research with Children'. Children and Society 12: 336-348.

Thompson, C. and Rudolph, L. (2000) Counseling Children. Belmont, CA: Wadsworth Brooks/Cole.

United Nations (1989) Convention on the Rights of the Child. Geneva: UN.

Veale, A. (2005) 'Creative Methodologies in Participatory Research with Children', in S. Greene and D. Hogan (eds) Researching Children's Experience. Approaches and Methods, pp. 253-272. London: Sage Publications. 
Waterman, A.H., Blades, M. and Spencer, C. (2001) 'Interviewing children and adults: The effect of question format on the tendency to speculate'. Applied Cognitive Psychology 15(3): 301-20.

Williamson, E., Goodenough, T., Kent, J. and Ashcroft, R. (2005) 'Conducting Research with Children: The Limits of Confidentiality and Child Protection Protocols'. Children and Society 19: 307-409.

Wood Charlesworth, L. and Rodwell, M.K. (1997) 'Focus groups with children: a resource for sexual abuse prevention program evaluation'. Child Abuse and Neglect 21(12): 1205-1216.

Young, L. and Barrett, H. (2001) 'Adapting visual methods: action research with Kampala street children'. Area, 33(2): 141-152. 